\title{
PENERAPAN SISTEM LISTRIK PLN PRABAYAR DENGAN PENGGUNAAN DAN PENGOPERASIAN KWH METER PRABAYAR SECARA IT DALAM E-PAYMENT SISTEM PULSA LISTRIK
}

\author{
Alfian Budianto dan Hoga Saragih \\ Fakultas Ilmu Komputer, Universitas Bina Nusantara, Jl. Kebon Jeruk Raya No. 27, Kebon Jeruk, Jakarta \\ Barat 11530, Indonesia \\ E-mail: hogasaragih@gmail.com
}

\begin{abstract}
Abstrak
Tujuan dari penelitian ini adalah membangun desain sistem pembayaran dan pengisian pulsa listrik prabayar secara online. Sistem listrik prabayar yang sedang berjalan masih menuai banyak permasalahan, misalnya saja sistem masih mengharuskan pelanggan listrik untuk membeli pulsa listrik secara offline dengan mendatangi outlet-outlet penjualan token listrik, ATM, ataupun melalui perantara pihak ketiga. Diharapkan sistem pembayaran dan pengisian pulsa listrik secara online dapat mengatasi permasalahan yang ada. Pelanggan dapat melakukan pengisian pulsa kapan saja secara online melalui website dan realtime. Metode analisis penelitian yang digunakan adalah analisis kuantitatif dan analisis kualitatif untuk mengukur respons pelanggan terhadap sistem listrik prabayar yang berjalan. Hasil dari implementasi sistem listrik prabayar secara online ini diharapkan dapat mendukung perusahaan PLN dalam mengembangkan perencanaan strategi teknologi informasi dan menghasilkan inovasi baru yang dapat menyelesaikan permasalahan pada sistem listrik prabayar sebelumya. Kesimpulan dari penelitian ini pembayaran dan pengisian pulsa listrik prabayar yang efektif dan efisien mempunyai pengaruh terhadap kepuasan dan kenyamanan pelanggan.
\end{abstract}

Kata Kunci: listrik, pembayaran, prabayar, website

\begin{abstract}
The purpose of this study is to develop online payment and prepaid electrical pulse charging system design. Prepaid electricity system is running still reap the many problems, such systems still require electricity customers to purchase electric pulse went offline with token sales outlets, electrical, ATM, or through third party intermediaries and other problems. Hopefully, online payment and charging electric pulses system can overcome the existing problems. Subscribers can reload at anytime online through website and realtime. Research methods that is used for analysis is quantitative and qualitative analysis, to measure customer responsse toward electrical prepaid system that has been running. The results of the implementation of online prepaid electricity system is expected to support the company PLN in developing information technology strategic planning and new innovations that can solve problems in electrical systems prepaid before. The conclusion from this study and the payment of electricity prepaid reload the effective and efficient to have an influence on customer satisfaction and comfort.
\end{abstract}

Keywords: electrical, payment, prepaid, website

\section{Pendahuluan}

Penerapan sistem listrik prabayar sudah diterapkan di Indonesia oleh PT. PLN Persero. Perkembangan teknologi dan internet telah membawa pengaruh yang besar dalam kehidupan masyarakat. Pada sistem listrik prabayar yang sedang berjalan, customer melakukan pengisian dengan membeli kode token listrik melalui ATM, Pos Penjualan Pulsa Listrik ataupun melalui Internet Banking. Setelah menentukan nilai pulsa listrik dan melakukan pembayaran, customer akan mendapatkan 20 digit kode token dengan nominal tertentu untuk dimasukkan ke meter listrik prabayar. Meter listrik prabayar akan mendeteksi 20 digit kode tersebut dan melakukan update pada memori. Customer dapat mengetahui total kredit pulsa yang dimiliki melalui layar LCD pada meter listrik.

Pembayaran dan pengisian listrik prabayar dengan sistem online menjadi perhatian untuk dikembangkan. Sebagaimana yang telah diterapkan juga di Afrika Selatan, di mana sistem pembelian token prabayar dilakukan secara online melalui web service. Setelah melakukan pembayaran customer akan mendapatkan kode token untuk dimasukkan ke meter prabayar sebagai pengisian pulsa. Customer tidak perlu lagi 
mendatangi pos tempat penjualan token listrik prabayar. Dengan melakukan migrasi dari sistem offline ke sistem online, customer baru dapat menggunakan fasilitas dari sistem listrik prabayar online. Customer hanya perlu login ke website dengan menggunakan username dan password yang dimiliki, lalu dapat memilih nominal kredit pulsa listrik yang diinginkan. Setelah itu customer dapat melakukan pembayaran secara online. Untuk dapat melakukan pembayaran secara online, diharuskan adanya kerjasama pihak perusahaan atau vendor listrik dengan pihak Bank. Sehingga adanya integrasi sistem online Banking dengan sistem pembayaran online dari perusahaan listrik. CDU (credit dispensing unit) akan mengenerate dan mengenkripsi kode token lalu oleh server akan ditampilkan ke customer dan customer dapat melakukan pengisian pulsa listrik dengan memasukkan token ke meter listrik [1].

Inovasi dalam pengembangan sistem listrik prabayar juga dilakukan dalam pengisian pulsa listrik secara online. Di mana dalam sistem ini diterapkan penggunaan smart card sebagai alternatif lain dari token listrik prabayar. Smart card ini paling banyak diterapkan dalam sistem listrik prabayar dan dapat melakukan pengisian pulsa dengan mengisi nominal kredit pulsa pada smart card. Customer dapat melakukan re-charge pulsa dengan membawa smart card ke pos / outlet penjualan pulsa listrik prabayar. Sebelumnya dilakukan pengembangan sistem dari vendor / perusahaan listrik yaitu pada pos penjualan pulsa dengan mengimplementasi GPRS connection. Petugas outlet akan mengisi kredit pulsa listrik pada smart card sesuai permintaan customer dengan menggunakan GPRS connection yang terhubung dengan server. Setelah itu customer dapat melakukan pembayaran dari pulsa listrik yang dibeli dan dapat melakukan pengisian pulsa pada meter listrik prabayar melalui smart card tersebut [2]. Pemanfaatan teknologi informasi dalam sistem listrik prabayar online juga digunakan dengan metode yang berbeda di Afrika Selatan. Pihak perusahaan listrik mengeluarkan meter listrik prabayar online di mana meter listrik tersebut dapat terkoneksi dengan server dengan memanfaatkan jaringan GSM. Customer dapat melakukan pembelian dan pengisian pulsa listrik secara online sama seperti pengisian pulsa prabayar pada handphone / mobile phone. Dalam meter listrik prabayar online terdapat sebuah smart card yang berfungsi sebagai identitas dari meter listrik milik customer. Customer dapat mendatangi outlet penjualan pulsa listrik untuk melakukan pembelian pulsa listrik. Ketika customer telah menentukan nominal kredit pulsa dan melakukan pembayaran, petugas akan segera melakukan pengisian secara online dengan mengirimkan informasi pulsa prabayar ke meter listrik milik customer berdasarkan ID meter. Lalu meter listrik akan mendeteksi dan memproses informasi pulsa listrik [3][4].

Dalam perkembangan teknologi informasi sekarang sudah dikenal teknologi baru yaitu teknologi broadband 4G. WiMAX telah muncul sebagai kandidat terbaik untuk membangun komunikasi yang lebih baik untuk masa depan. Pemanfaatan WiMAX connection juga diterapkan pada sistem listrik prabayar, dalam proses pengisian pulsa listrik prabayar secara real-time. Dalam hal ini dapat dibuat skema smart prepaid meter berbasis autentifikasi secara terpusat (centralized) dan pengisian pulsa listrik dengan menggunakan WiMAX prepaid accounting model [5]. Pengembangan dan pengujian tidak hanya dilakukan pada sistem komunikasi pada sistem listrik prabayar, tetapi juga pada tingkat kemungkinan error dari kinerja meter listrik prabayar. Penelitian dilakukan dengan menganalisa proses dan sistem yang bekerja pada meter listrik, sehingga dapat diketahui kemampuan dan cara kerja meter prabayar. Sebagai hasil dari pengujian pada mikrokontroller AT89C2051 pada meter prabayar dapat diketahui bahwa tingkat error dari meter listrik prabayar sangat kecil dibandingkan meter listrik dengan sistem pascabayar, di mana petugas secara periodik harus melakukan pengecekan meter listrik milik pelanggan [6].

Untuk mengatasi permasalahan pada sistem listrik prabayar yang berjalan yang diselenggarakan oleh PLN dapat dilakukan pengembangan sistem listrik prabayar secara online. Customer dapat melakukan pembelian token pulsa dan melakukan re-charge pulsa listrik secara online. Customer tidak perlu lagi mendatangi dan antri di pos/outlet

penjualan token, ATM, dan melakukan pengisian pulsa secara manual dengan memasukkan kode token ke meter listrik. Pembelian kode token pulsa dapat dilakukan melalui webservice, dan pengisian pulsa listrik dilakukan secara online dan real-time. Sehingga pembelian dan pengisian pulsa pulsa listrik dapat dilakukan kapan dan di mana saja dengan koneksi internet.

\section{Metodologi}

Sampel akan diambil menggunakan teknik Random Sampling / Probability sampling dimana pengambilan sampel yang memberikan kesempatan yang sama untuk diambil kepada setiap elemen populasi. Pengambilan jumlah sampel, peneliti akan menggunakan metode Slovin dengan persamaan 1 berikut: 


$$
n=\frac{N}{N d^{2}+1}
$$

Di mana :

$\mathrm{n}=$ Jumlah sampel minimal

$\mathrm{N}=$ Ukuran populasi

$\mathrm{d}=$ Presisi yang digunakan 90\% (toleransi kesalahan 10\%)

$$
\begin{gathered}
n=\frac{1000}{1000(0.1)^{2}+1} \\
n=90.9090
\end{gathered}
$$

Tingkat presisi yang digunakan peneliti adalah 90\%, alasannya karena populasi yang peneliti gunakan adalah kurang lebih 1000 orang, sehingga toleransi untuk terjadi kesalahan adalah $10 \%$. Dengan perhitungan tersebut didapatkan jumlah sample adalah 90,90 dibulatkan menjadi 91. Penyebaran kuisioner secara online melalui http://kwiksurveys.com/onlinesurvey.php?surveyID=LKMOGN_da9ffda4

Gambar 1 merupakan grafik pelanggan dalam membayar listrik. Sedangkan tingkat ketertarikan pelanggan dengan penerepan sistem prabayar di rumah, digambarkan pada grafik gambar 2. Gambar 3 menggambarkan grafik tingkat ketertarikan pelanggan dengan penerapan sistem prabayar di tempat usaha.

\section{Tempat Pembayaran Tagihan Listrik}

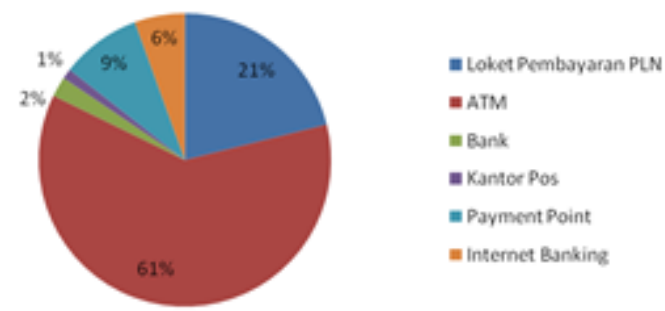

Gambar 1.Grafik pelanggan dalam membayar listrik.

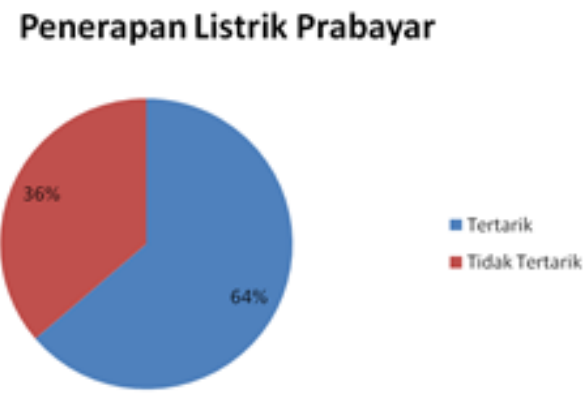

Gambar 2. Grafik tingkat ketertarikan pelanggan dengan penerapan sistem prabayar di rumah.

\section{Penerapan Listrik Prabayar di Tempat Usaha}

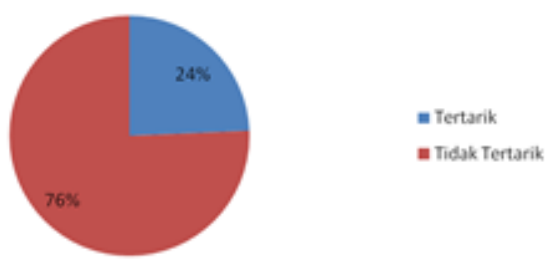

Gambar 3. Grafik tingkat ketertarikan pelanggan dengan penerapan sistem prabayar di tempat usaha.

\section{Permasalahan Listrik Prabayar Berjalan}

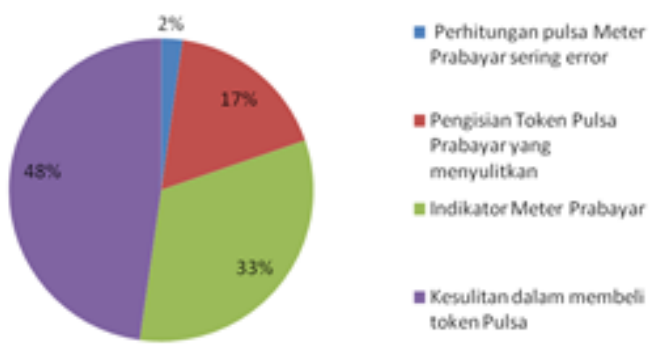

Gambar 4. Grafik tingkat kesulitan pelanggan listrik prabayar yang berjalan.

\section{Penilaian Listrik Prabayar Berjalan}

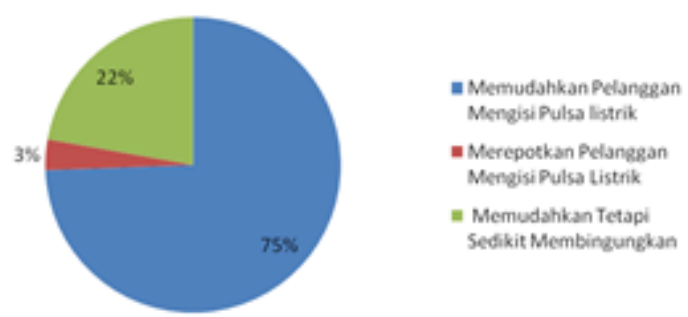

Gambar 5.Grafik respons pelanggan terhadap listrik prabayar yang berjalan.

\section{Penerapan Listrik Prabayar Online}

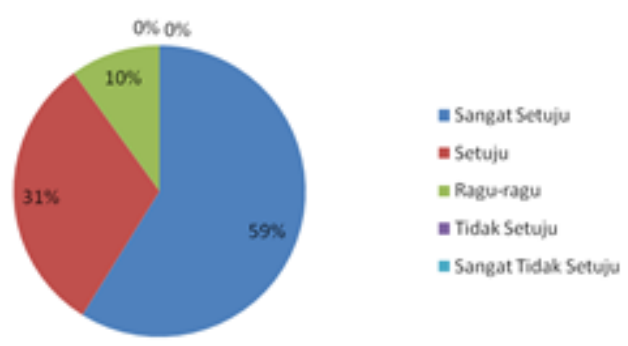

Gambar6. Grafik penerapan listrik prabayar online.

Gambar 4 menggambarkan grafik tingkat kesulitan pelanggan listrik prabayar yang berjalan. Berikutnya gambar 5 dan gambar 6 berturut-turut 
menggambarkan grafik respons pelanggan terhadap listrik prabayar yang berjalandan grafik penerapan listrik prabayar online.

\section{Hasil dan Pembahasan}

Berikut adalah proses secara keseluruhan dari sistem listrik prabayar. Pada gambar 7 menunjukkan proses migrasi customer dari sistem offline ke sistem online. Customer melakukan pendaftaran dan membuat account terlebih dahulu ke Vending Station dari Perusahaan Listrik serta melakukan pembayaran administrasi. Customer akan memperoleh vending device berupa smart card, kartu pelanggan, dan meter listrik prabayar online. Setelah melakukan pemasangan listrik, customer dapat memasukkan pada smart card ke meter listrik, dan melakukan pengisian kredit pulsa listrik prabayar. Smart card berfungsi sebagai identitas dari meter listrik. Customer dapat mengakses alamat website yang diberikan oleh petugas setelah membuka account, dan login untuk membeli dan mengisi pulsa listrik. Customer dapat memilih nominal pulsa yang ingin dibeli dan melakukan pembayaran secara online dengan menggunakan rekening Bank yang didaftarkan sebelumnya. Dalam hal ini terdapat kerjasama antara pihak perusahaan listrik dengan Bank. Server akan men-generate dan mengenkripsi token listrik lalu mengirim dan menampilkan ke halaman customer, sehingga customer mendapatkan kode token listrik. Lalu customer dapat meng-input ID smartcard yang ada pada meter listrik dan melakukan pengisian pulsa listrik secara online. Server akan melakukan rating entity, yaitu mengubah nilai kredit pulsa ke dalam unit daya listrik. Hasil dari proses ini disebut dengan quota. Selanjutnya server akan mengirim informasi quota ini ke OnlinePrepaid Meter menggunakan WiMAX connection (4G) berdasarkan dengan ID dari smart card yang telah dimasukkan customer. ID pada smart card ini juga sudah terdaftar dalam account dari customer. Prepaid Meter akan menerima quota tersebut dan menga-update kredit pulsa listrik prabayar. Selanjutnya customer dapat melakukan pengecekan total kredit pulsa listrik pada layar LCD Prepaid Meter.

Dari gambar 8 customer dapat melakukan pengisian pulsa (credit) prabayar dengan mengakses web service yang telah dibangun. Setelah melakukan authentifikasi customer dapat melakukan transaksi dan pembayaran pulsa prabayar. Lalu Online Vending
Server akan melakukan generate untuk kode token dan mengirimkan / menampilkan kembali kode token kepada client sesuai nominal yang dibeli oleh customer, sebagai verifikasi.Server melakukan enkripsi terhadap kode token yang dikirim ke client untuk menjamin keamanan. Selanjutnya customer memasukkan (input) nomor / ID smart card untuk melakukan proses pengisian pulsa listrik secara online. Server akan melakukan rating entity, yaitu untuk men-convert kredit ke dalam unit daya listrik yang hasilnya biasa disebut dengan Kuota. Informasi Kuota inilah yang akan dikirimkan oleh server ke sistem meter prabayar milik customer menggunakan WiMAX (4G) Connection, sesuai ID_Meter yangdiidentifikasi. Kemudian customer dapat melakukan pengecekan total kredit pulsa listrik melalui LCD pada meter prabayar.

Gambar 9 menunjukkan model arsitektur yang diusulkan. Model yang diusulkan terdiri dari tiga entitas logical yaitu Prepaid Smart Meter, ASN, dan CSN di mana telah sesuai dengan arsitektur WiMAX Prepaid Accounting [5].

Menurut WiMAX Forum, arsitektur Mobile WiMAX terdiri dari 3 bagian pokok, yaitu user terminal yang digunakan oleh end-user untuk mengakses jaringan, access service network (ASN) yang terdiri dari satu atau lebih BS dan satu atau lebih ASN gateway yang membentuk jaringan akses radio, dan connectivity service network (CSN) yang menyediakan konektivitas IP dan semua fungsi core Network Internet Protocol [7].

Network Working Group (NWG) WiMAX Forum merupakan organisasi yang mempunyai kewenangan untuk merancang arsitektur jaringan dan protocol Mobile WiMAX dengan air interface yang telah distandarkan oleh IEEE 802.16e.

WiMAX NGW mendefinisikan beberapa entity dalam jaringan Mobile WiMAX [7]. Pertama, Base Station (BS). Base Station memiliki fungsi utama yaitu membangun hubungan dengan mobile station.BS juga memiliki fungsi lain yaitu mengatur micromobility management seperti proses handover, radio resource management. Kedua, Access Service Network - Gateway (ASN-GW).ASN-GW berfungsi untuk mengatur location management dan paging intra-ASN, mengatur AAA pelanggan, serta menjalankan fungsi mobile IP.Ketiga, Connectivity Service Network (CSN) berfungsi menyediakan konektivitas ke internet, ASP dan fungsi jaringan umum lainnya. 

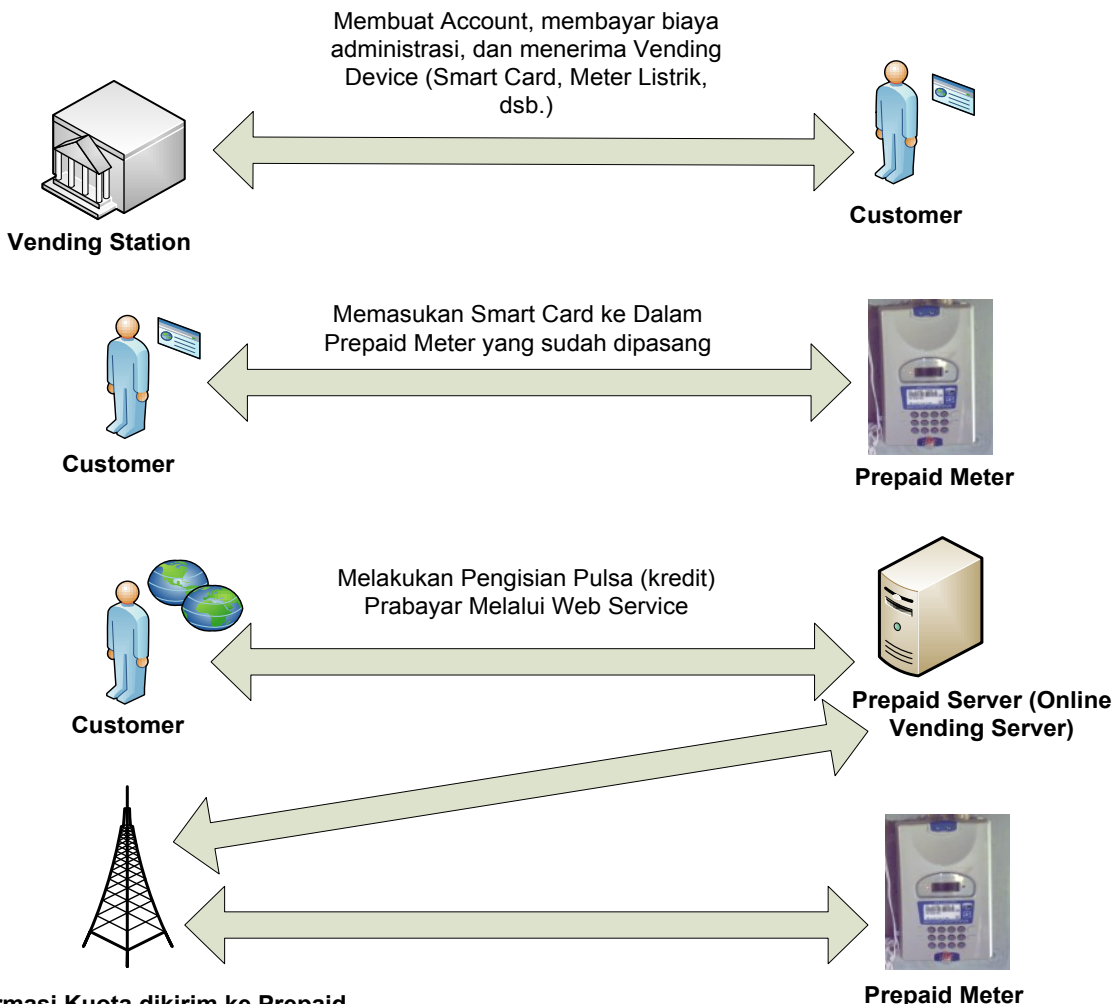

Informasi Kuota dikirim ke Prepaid Meter dengan WiMAX (4G)

$$
\text { Connection }
$$

Gambar 7. Proses sistem listrik prabayar secara umum.

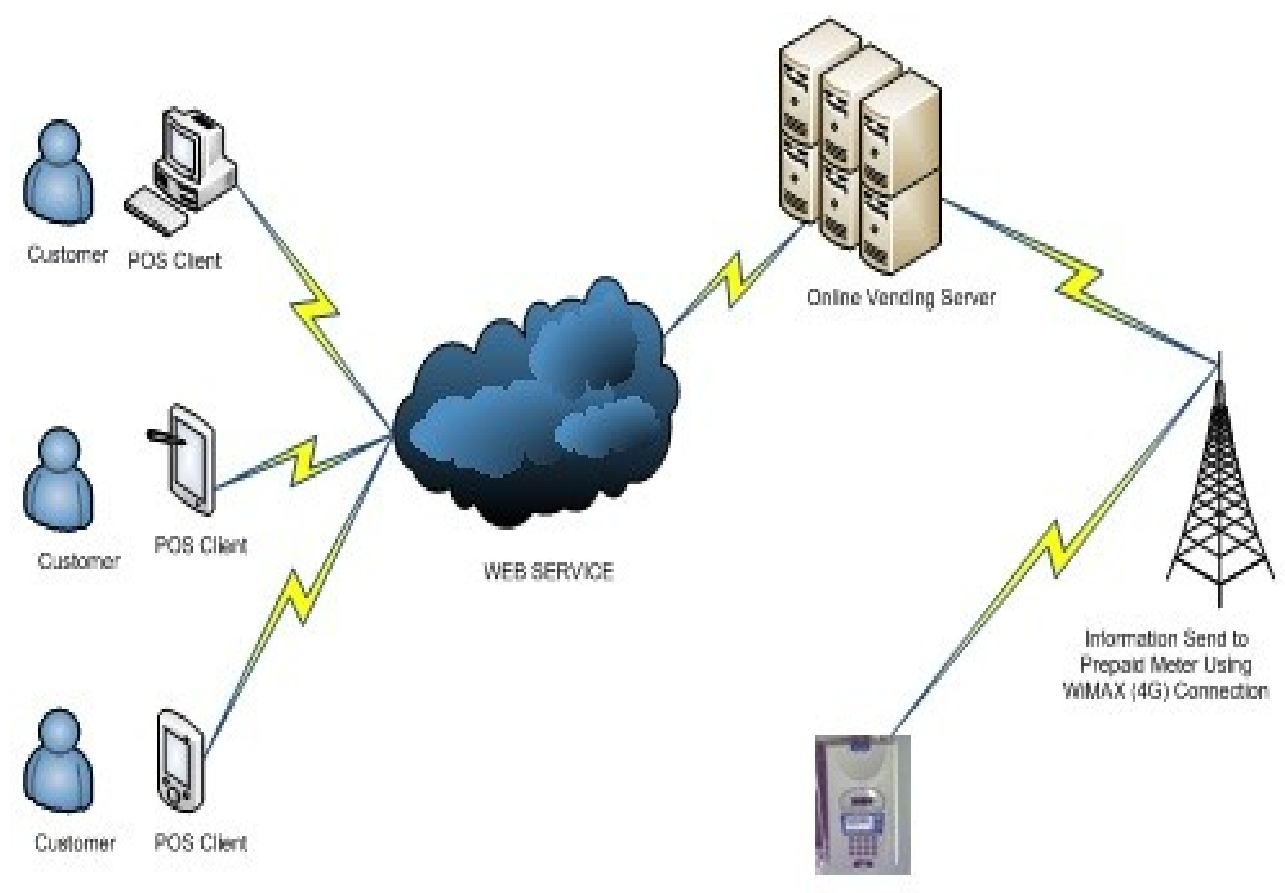

Prepsid Meter

Gambar 8. Arsitektur sistem prabayar. 


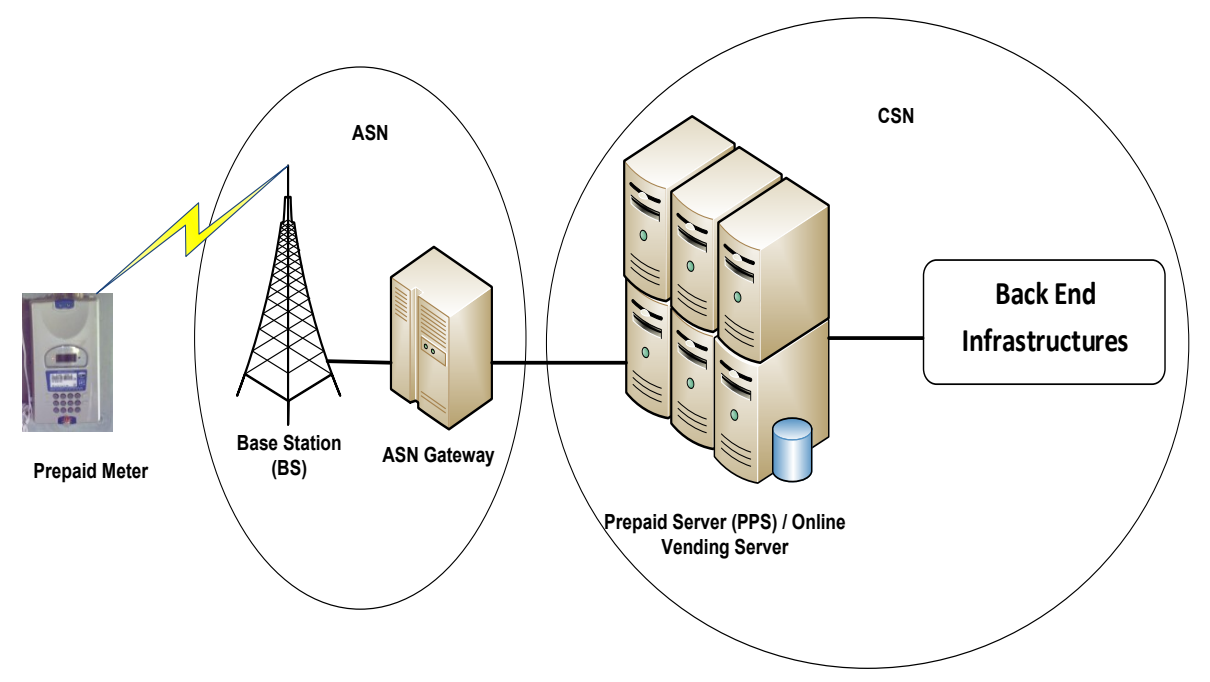

Gambar 9. Proses charging pulsa listrik

Dengan adanya Smart Card yang diterapkan pada sistem listrik prabayar menjadikan sistem pembayaran listrik dan pengendalian listrik menjadi lebih efektif. Smart Card di harapkan dapat mengelola konsumsi listrik di sebuah tempat tinggal atau hotel. Dengan demikian customer dapat mengkonsumsi daya hanya sebanyak yang mereka butuhkan. Dengan kata lain konsumsi listrik berada pada tanggung jawab customer [8][9]. Gambar 10 menunjukkan use case diagram untuk sistem listrik prabayar. Gambar 11 merupakan sequence diagram proses pendaftaran sistem listrik prabayar, sedangkan gambar 12 menggambarkan sequence diagram pada saat proses pembelian token listrik secara online.

Berikutnya pada gambar 13 merupakan proses charging pulsa listrik prabayar secara online. Server selain melakukan generate pulsa listrik berupa token juga melakukan rating entity, yaitu mengubah nilai kredit pulsa ke dalam unit daya listrik dan hasil dari proses ini disebut dengan quota [5]. Kuota inilah yang akan dikirim prepaid server ke meter listrik. Proses pengisian terdiri dari tiga sesi [5]. Pertama, session initialization. Ketika PPC (Prepaid Client) terhubung dalam jaringan, server akan melakukan pembangunan koneksi (initiates) yaitu prosedur autentifikasi dan autorisasi dengan mengirim access request message. Access request message berisi ID meter dan volume kuota. Setelah meter menerima access request message, meter akan mengidentifikasi dan menvalidasi. Setelah itu meter akan memberikan autorisasi dengan mengirim paket request ke server untuk mengidentikasikan bahwa service siap dijalankan. Server akan menerima paket request dari meter tersebut dan siap menjalankan proses selanjutnya.
Proses kedua, mid session negotiation, server akan mengirim access request message ke meter prabayar online. Meter akan mendeteksi dan menvalidasi message dari server setelah menvalidasi message authentificator field. Server mendeteksi PPC (Prepaid Client) yaitu meter listrik berdasarkan ID yang tertanam dalam meter. Server akan menyediakan kuota untuk dialokasikan ke meter listrik. Setelah berhasil melakukan pengiriman kuota, meter akan mendeteksi kuota tersebut dan melakukan update ke dalam memori. Pelanggan dapat melakukan pengecekan pada meter dan kredit pulsa listrik akan ditampilkan melalui layar LCD meter listrik. Proses ketiga, session termination.Pada tahap ini merupakan kondisi ketika layanan dihentikan (service is terminated) dan ketika PPC (Prepaid Client) yaitu meter listrik telah menerima pesan putus dari PPS (Prepaid Server/Online Vending Server).

Relational Database Management System (RDBMS) menyediakan solusi yang bagus untuk menyimpan dan mengakses informasi yang kompleks. Pada sistem ini menggunakan MySQL [2][10], yaitu merupakan database relasional open source. Pada gambar 8 di bawah menunjukkan hubungan entitas dari database sampel. Terdapat 5 entitas, seperti pada gambar 14, yaitu entity card_info, ending_info, user_account_info, vending user account info, - - dan vending_usr_balance_update_info.

Standard Transfer Spesification (STS) dikembangkan sebagai spesifikasi dari Eskom. STS dapat didefinisikan sebagai protokol secure message yang memungkinkan arus informasi yang aman antara CDU (Credit Dispensing Unit) dan meter. 


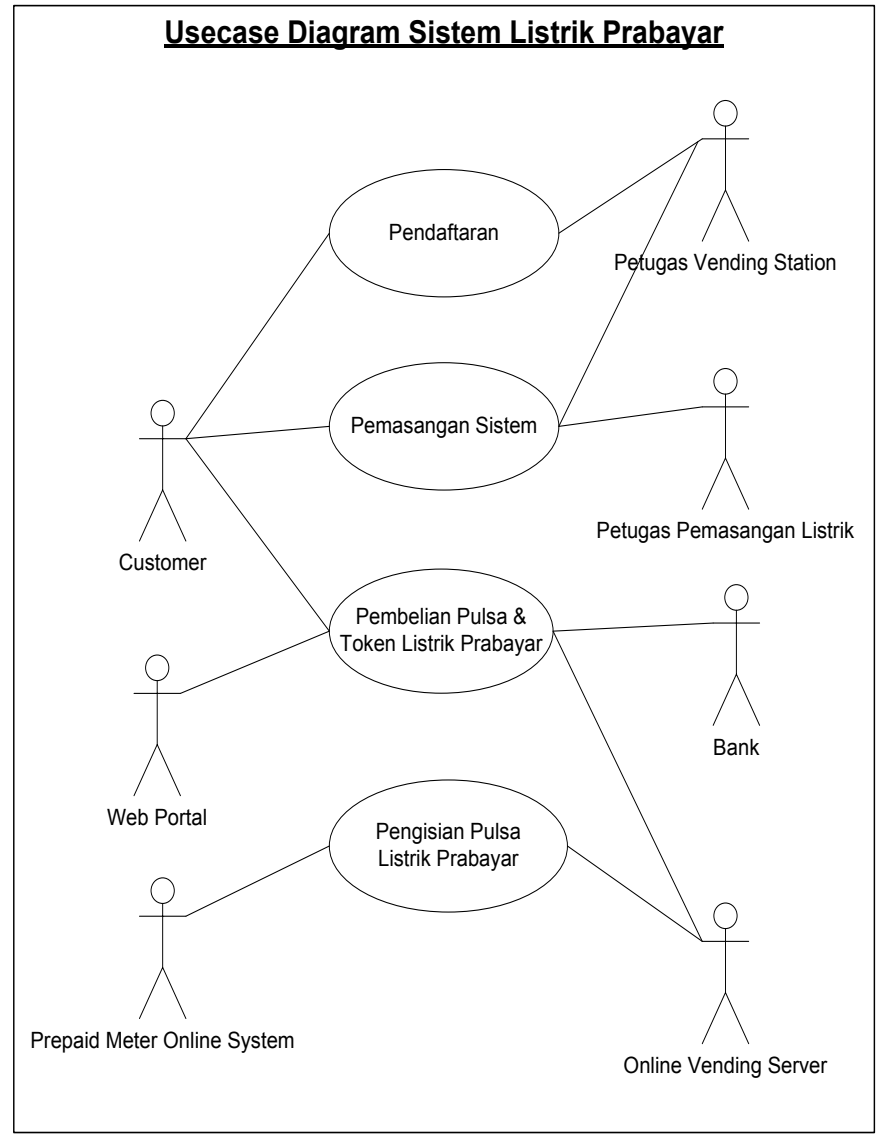

Gambar 10. Use case sistem listrik prabayar.



Gambar 11. Sequence diagram pendaftaran listrik prabayar. 


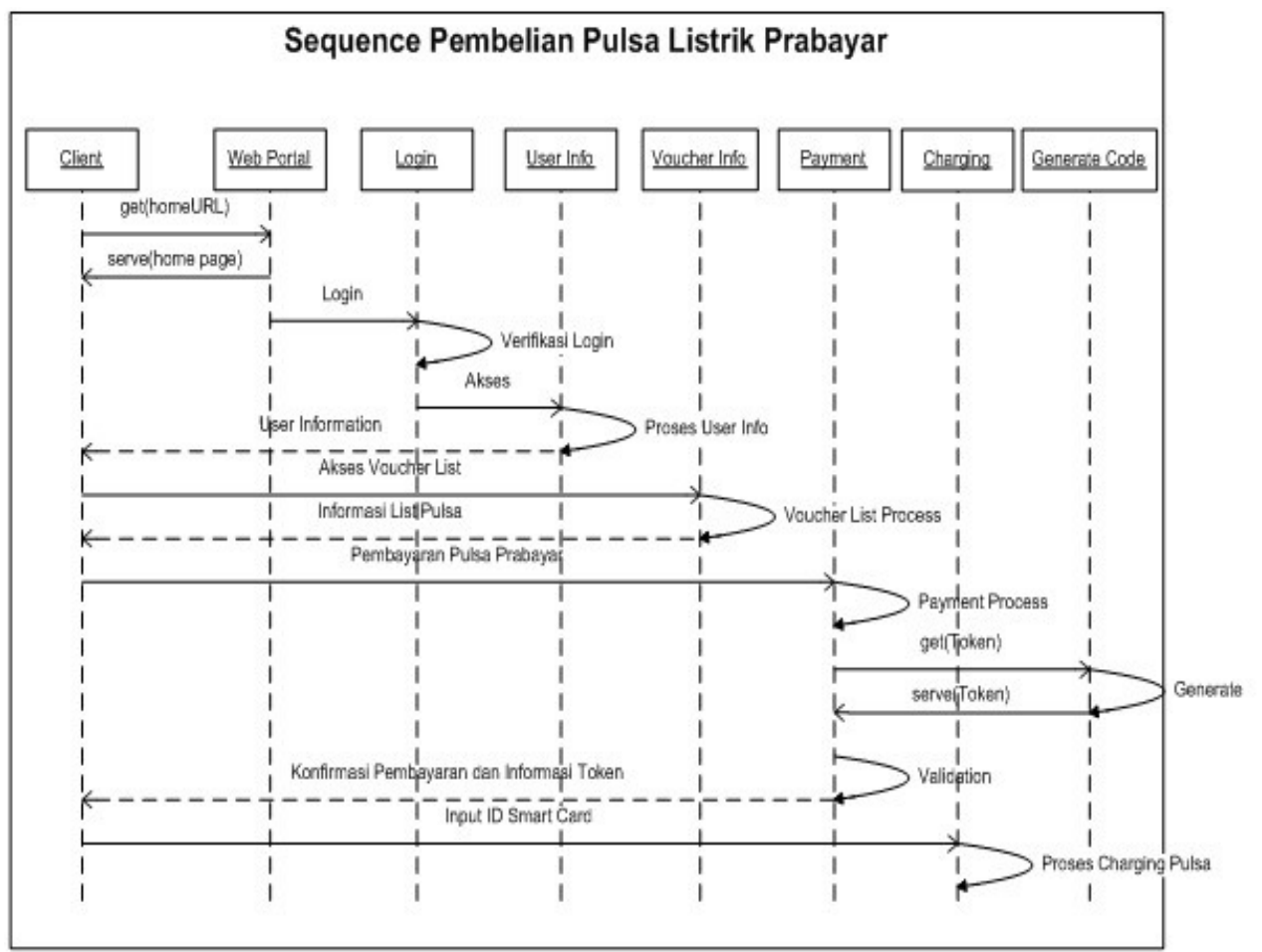

Gambar 12. Sequence diagram pembelian tokenlistrik secara online.

\section{Sequence Pengisian Pulsa Prabayar}

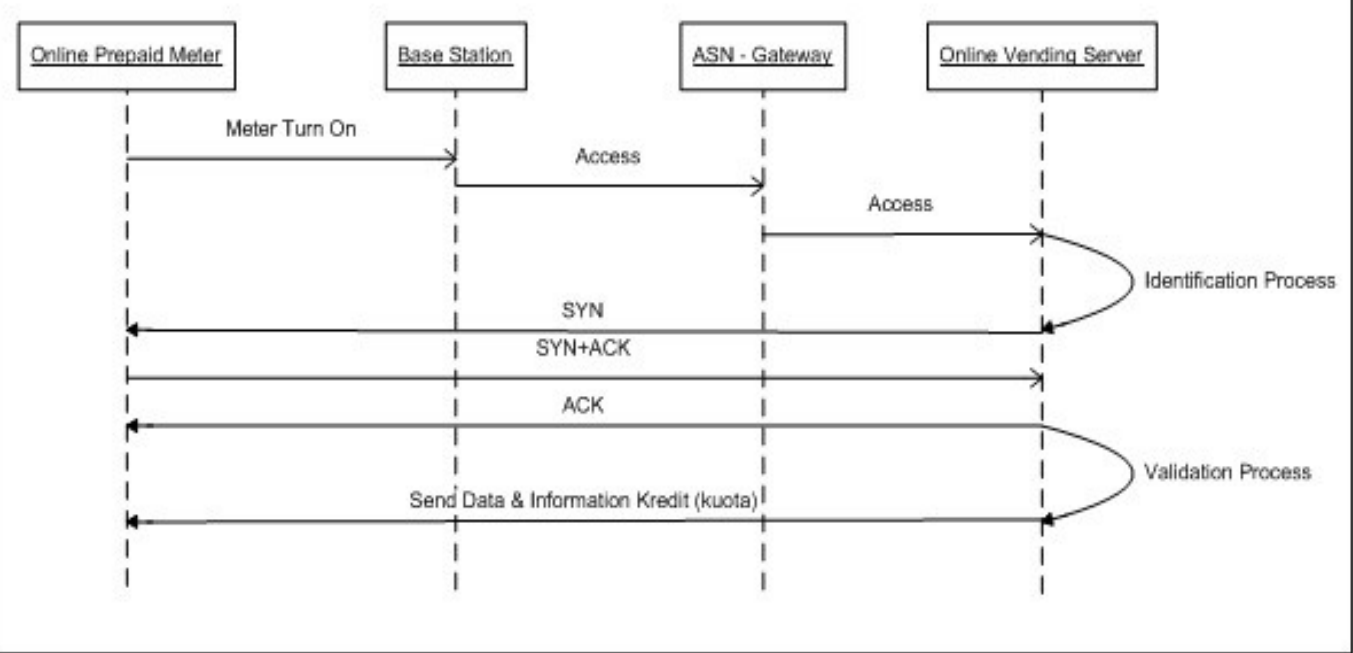

Gambar 13.Sequence diagram pengisian pulsa prabayar.

CDU merupakan unit yang berfungsi menggenerate kode token untuk listrik prabayar. Informasi yang dibawa antara CDU dan meter di enkripsi oleh protokol ke dalam sebuah fixed length value yang disebut sebagai token.NRS 009 merupakan serangkaian spesifikasi yang menjelaskan persyaratan minimum yang relevan untuk pelaksanaan pembayaran dari sistem penjualan listrik prabayar. NRS 009 menggambarkan standard transfer spesification (STS) di mana transaksi dapat secara aman ditransfer dari Pos penjualan / POS (Point Of Sales) ke peralatan listrik pelanggan dengan cara data dienkripsi pada token. Token encoding format sebagai berikut [11-14]: binary formatdan decimal format.Gambar 15 merupakan desain Blok 
Diagram untuk meter listrik prabayar online (online smart prepaid meter) yang diusulkan dalam penulisan paper ini.

Dalam hal ini yang peneliti lakukan adalah menambahkan smart card reader, WiMAX Modem, dan LCD Display dari blok diagram pada umumnya. Mikrokontroler yang digunakan adalah AT89C2051 sebagaimana yang telah dilakukan pengujian dengan tingkat error yang kecil [6].
Modem WiMAX digunakan untuk dapat melakukan koneksi ke internet. Meteran akan teridentifikasi oleh server dengan adanya smart card yang tertanam dalam smart card reader. Microcontroller AT89C2051 akan mengidentifikasikan data yang masuk. Setelah itu data quota tersebut disimpan dalam memory dan sistem siap untuk mendeteksi jumlah putaran piringan KWH meter.



Gambar 14. ERD diagram sistem listrik prabayar.

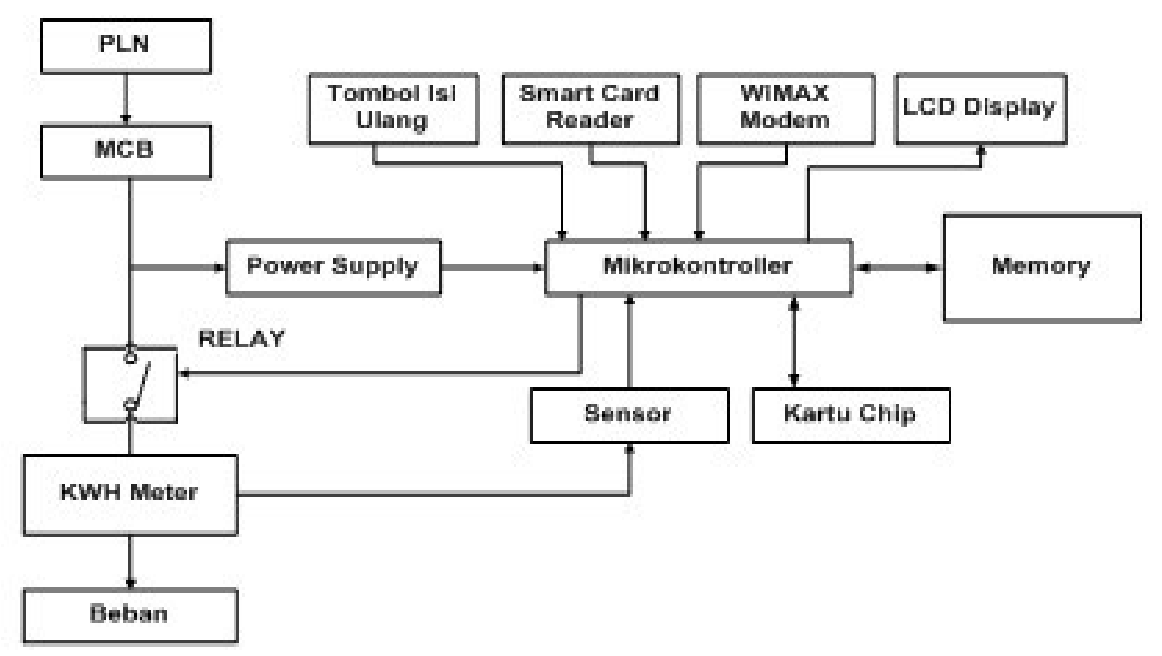

Gambar 15. Blok diagram meter listrik. 
Untuk sejumlah putaran tertentu maka unit yang ada di memory akan dikurangi satu unit, hingga habis. Isi dari memory ini dapat ditambah dengan melakukan proses isi ulang. LCD pada meter listrik kemudian menampilkan informasi tentang sisa pulsa. MCB yang berfungsi sebagai pembatas arus sekaligus pengaman bila terjadi short circuit. Kemudian dialirkan juga ke KWH meter yang berfungsi untuk menghitung daya yang terpakai.

Relay berfungsi sebagai penghubung atau pemutus aliran listrik dari MCB ke KWH meter. Relay ini dikontrol oleh mikrokontroler AT89C2051. Listrik dari MCB selain dialirkan ke KWH meterjuga dialirkan ke power supply yang berfungsi untuk memberikan supply tegangan ke rangkaianmikrokontroler. Sensor infrared dan photodiode dipasang pada KWH meter sedemikian rupasehingga dapat mendeteksi garis penanda pada piringan KWH meter. Output sensor ini dihubungkan ke mikrokontroler, supaya mikrokontroler AT89C2051 dapat menghitung jumlah putaran piringan KWH meter. 'Kartu Chip' dan memory yang berupa serial EEPROM dipakai untuk menyimpan informasi jumlah putaran piringan KWH meter yang masih diperbolehkan. Pada sistem juga dipasang LCD display dan tombol untuk proses isi ulang.Jika unit nominal pada memory telah habis, maka mikrokontroler akan mematikan relay sehingga aliran listrik terputus. Relay akan aktif kembali jika memory tersebut telah diisi ulang.

Pada server side vending system, web server yang digunakan dalam desain sistem dari server side adalah Apache. Web server ini merupakan platform yang independen, open source dan mendukung server side scripting language untuk berkomunikasi dengan database.Protokol HTTP membentuk dasar untuk komunikasi secara keseluruhan pada web, bersama-sama dengan protokol SSL (Secure Socket Layer) dan APACHE (BS2000/OSD) [15].

Server side scripting language PHP digunakan dalam desain sistem ini untuk mendapatkan informasi dan melakukan pertukaran informasi melalui web portal yang dilakukan oleh customer, sekaligus pertukaran dan pengiriman data pada proses pengisian (charging) pulsa prabayar antara server ke online prepaid meter. Bahasa ini bekerja bersama web server untuk menafsirkan request dari customer melalui World Wide Web (www). Dalam proses request ini, berinteraksi dengan program lain pada server untuk memenuhi request tersebut dan kemudian menampilkannya pada web server untuk melayani sistem client [16].

Relational Database Management System (RDBMS) menyediakan cara yang baik untuk menyimpan dan mengakses informasi yang kompleks. Dalam sistem ini database relasional open source MySQL digunakan untuk tujuan tersebut[10].

Pada client side vending system, AT89C2051 merupakan mikrokontroler dengan low-voltage, high-performance mikrokomputer CMOS 8-bit dengan 2Kbyte Flash programmable dan ereaseable read only memory (PEROM). Mikrokontroler ini diproduksi menggunakan teknologi high-density nonvolatile memory dari Atmel dan kompatibel dengan set standar industri MCS-51 instruction[17]. Beberapa ATCommand dapat digunakan untuk menghubungkan beberapa device [18].

AT93C46/56/66

menyediakan $1024 / 2048 / 4096$ bit memori (EEPROM) yang diatur dalam 64/128/256 kata dari 16 bit masingmasing, pin ORG terhubung ke VCC dan $128 / 256 / 512$ kata dari 8 bit masing-masing di mana hal itu terikat pada ground. Perangkat ini dioptimalkan untuk digunakan dalam aplikasi industri dan komersial di mana daya rendah dan operasi tegangan rendah sangat penting. AT93C46/56/66 tersedia dalam space yang kecil 8-lead PDIP, 8-lead JEDEC SOIC, 8-lead EIAJ SOIC dan 8-lead TSSOP[19].

Smart Card yang digunakan dalam desain ini adalah SLE 5542, merupakan kartu cerdas dengan 256 byte EEPROM dan Write Protection Function and Programmable Security Code (PSC) [20-22]. Smart card reader digunakan untuk membaca smart card dan memodifikasi data pengguna. Dalam sistem ini, SLE 5542 adalah smart card yang digunakan [20-22].

WiMAX modem adalah device yang digunakan untuk terhubung ke internet. Hal ini memungkinkan sistem listrik prabayar dapat berjalan secara online.UART serial dari mikrokontroler digunakan untuk komunikasi serial dengan modem. Unit AT89C2051 memiliki transmit pin, receive pin, dan external clock pin [23]. LCD Display pada Meter Listrik Prabayar berfungsi untuk menampilkan informasi tentang kredit (kuota) pulsa prabayar dan digunakan untuk membantu dalam melakukan pengisian pulsa prabayar dengan memasukan kode token secara manual. Keypad pada meteran listrik berfungsi untuk memasukan kode token secara manual dalam pengisian pulsa prabayar. Web browser digunakan untuk mengakses web portal dalam proses pembelian pulsa listrik prabayar dan pengisian pulsa listrik secara online.

\section{Kesimpulan}

Berdasarkan hasil penelitian ini dapat diambil kesimpulan bahwa sistem listrik prabayar 
secara online sesuai dengan kebutuhan customer dan dapat memudahkan customer dalam melakukan pembelian token / pulsa listrik dan pengisian pulsa listrik secara online dan real-time. Sehingga customer dapat melakukan pengisian pulsa kapan dan di mana saja dengan menggunakan koneksi internet. Customer tidak harus mengantri di depan ATM, POS penjualan token listrik, ataupun tidak harus melakukan pengisian pulsa listrik secara manual.

Dalam makalah ini peneliti menyediakan sebuah studi dari WiMAX untuk diimplementasikan dalam sistem listrik prabayar. Studi ini juga digunakan untuk menyajikan sistem listrik prabayar dengan pengisian meter listrik yang digunakan dalam aplikasi Smart Grid.

\section{Ucapan Terima Kasih}

Penulis mengucapkan banyak terima kasih kepada Bapak Dr. Hoga Saragih, ST., MT., selaku pembimbing saya yang telah membantu penyusunan makalah ini serta memberikan masukan dan saran sehingga selesainya makalah ini dibuat.

\section{Referensi}

[1] K.P. Subramoney \&Prof. G. P. Hancke, "A Secure Web Service for Electricity Prepayment Vending in South Africa"In Second International Conference on Internet and Web Applications and Services, p. 66, 2007.

[2] M.M. Islam, K. H. Ansary, S.M.T. Ahmad, L.Ali, A.H. Chowdhury, \&S.M.L.Kabir, "Developtment of Low Cost Portable Vending System for Prepaid Utility Meter"In Proceedings of The International Conference on Industrial Engineering and Operations Management, pp. 644-649, 2011.

[3] L. E. Sebola \&W.T. Penzhorn, "A Secure Mobile Commerce System for the Vending of Prepaid Electricity Tokens"InProceedings of the Southern African Telecommunications Networks and Applications Conference (SATNAC), 2003.

[4] A.Jain \&M.Bagree, “A prepaid meter using mobile communication, "International Journal of Engineering, Science and Technology,vol.3, pp.160-166, 2000.

[5] R.H. Khan, T.F. Aditi, V.Sreeram, \&H.H. C. $\mathrm{Iu}$,"A Prepaid Smart Metering Scheme Based on WiMAX Prepaid Accounting Model,"Smart Grid and Renewable Energy, vol. 1, pp. 63-69, 2010
[6] L.L.U. Tung \&H.Oktavia,"KWH Meter Dengan Sistem Prabayar"In Proceedings, Komputer dan Sistem Intelijen (KOMMIT 2002), pp. B-27-B-33, 2002.

[7] WiMAX Forum, Network Architecture WiMAX Forum Document Number, WMFT32-002-R010v04, 2009.

[8] M.W. Raad, T. Sheltami, \&M. Sallout, "A Smart Card Based Prepaid Electricity System" In 2nd International Conference on Pervasive Computing and Applications, pp. 219-224, 2007.

[9] J. Newbury\&W. Miller, "Smart Prepaid Energy Meter Implementation" In Power DeliveryIEEE, pp. 1-5, 2002

[10] MySQL, MySQL Enterprise Edition Product Guide, http://www.mysql.com/, 2001, retrieved June $12,2008$.

[11] National Rationalised Specification, Interface Standards: Data Transfer by physical media - System Master Station Credit dispensing unit, NRS 009-6-4.

[12] National Rationalised Specification, Key management: Standard transfer specification/The management of cryptographic keys, NRS 009-7.

[13] National Rationalised Specification, Functional and performance requirements: System master stations, NRS 009-2-1.

[14] National Rationalised Specification, Functional and performance requirements: Credit dispensing units, NRS 009-2-2.

[15] Apache BS2000_v2.2 Datasheets, Fujitsu, 2009.

[16] Php, Database Issues, http://php.net/index.php, 2003, retrieved April 1, 2007.

[17] AT89C2051 Datasheet, Atmel Corporation, San Jose, 2000.

[18] ATCommand SIM300D_ATC_V1.06 Datasheets, SIMCOM, 2006.

[19] AT93C46 Datasheet, Atmel Corporation, San Jose, 2002.

[20] SLE 5542 Datasheet, Infineon Technologies AG, Munich, 2006.

[21] Software Resolution, Smart Card Readers, http://www.softwaresolution.org/smart_card readers.html, 2003, retrieved April 1, 2008.

[22] Smart Card Alliance, Planning for New Fare Payment and Collection Systems: Cost Considerations and Procurement Guidelines, http://www.smartcardalliance.org,2010, retrieved July 12, 2010.

[23] Motorola WiMAX CPEi 775 Datasheet, Motorola, United State of America, 2010. 